\title{
Correction: Laboratory-based intermountain validated exacerbation (LIVE) Score stability in patients with chronic obstructive pulmonary disease
}

Blagev DP, Collingridge DS, Rea S, et al. Laboratory-based Intermountain Validated Exacerbation (LIVE) Score stability in patients with chronic obstructive pulmonary disease. BMJ Open Resp Res 2020;7:e000450. doi: 10.1136/bmjresp-2019-000450

In this article author wants to add about the funding source of the study as follows:

MA and SZ were supported by a grant from the Flight Attendant Medical Research Institute.

\section{(る) \\ OPEN ACCESS}

Open access This is an open access article distributed in accordance with the Creative Commons Attribution Non Commercial (CC BY-NC 4.0) license, which permits others to distribute, remix, adapt, build upon this work non-commercially, and license their derivative works on different terms, provided the original work is properly cited, appropriate credit is given, any changes made indicated, and the use is non-commercial. See: http://creativecommons.org/licenses/by-nc/4.0/.

(c) Author(s) (or their employer(s)) 2020. Re-use permitted under CC BY-NC. No commercial re-use. See rights and permissions. Published by BMJ.

BMJ Open Resp Res 2020;7:e000450corr1. doi:10.1136/bmjresp-2019-000450corr1

A) Check for updates 